\title{
Biochemical genetics of blackfly isozymes I. Isozyme variation among three species, Simulium ochraceum, S. metallicum and S. horacioi from Guatemala*
}

\author{
Takeshi Agatsuma, ${ }^{* *}$ Kiichi Uemoto ${ }^{* * *}$ and J. Onofre Ochoa A. ${ }^{* * * *}$ \\ ** Department of Parasitology, Kochi Medical School, Oko, Nankoku 781-51, Japan \\ *** Department of Medical Zoology, Kyoto Prefectural University of Medicine, \\ Kawaramachi Hirokoji, Kyoto 602, Japan \\ **** Laboratorio de Investigación Cientifica para Control de la Oncocercosis, SNEM, \\ 5a Ave. 11-40, Zona 11, Guatemala, Guatemala
}

(Received: April 17, 1985)

Key words: blackfly, electrophoresis, isozyme, biochemical genetics, species identification, Guatemala.

\begin{abstract}
Isozyme variations of Guatemalan blackflies, Simulium ochraceum, S. metallicum, $S$. horacioi, were studied using starch gel electrophoresis. Three out of seven enzymes examined, alkaline phosphatase, $\alpha$-glycerophosphate dehydrogenase and leucine aminopeptidase were found to show developmental changes in their respective electrophoretic patterns, suggesting some regulatory mechanism in the gene activity. Two enzymes, glucosephosphate isomerase and phosphoglucomutase, showed high polymorphism in every species studied, and the remaining enzymes, monomorphism. We found marked differences in electrophoretic patterns among the three species. Two methods, that is, Nei's genetic distance $(D)$ and allelic distance $\left(A_{\mathrm{D}}\right)$, were used to calculate genetic distances among them. Both estimations of genetic distances showed that $S$. ochraceum is remote from the other two species, though the distance estimate between $S$. ochraceum and $S$. horacioi is rather small. Surprisingly, $S$. horacioi, which is considered to be very close to $S$. metallicum, showed a rather large distance from this allied species, indicating that they are not so close.
\end{abstract}

\section{INTRODUGTION}

Blackflies in the family Simuliidae are an evolutionarily interesting group, because

* This study was supported by the Ministry of Public Health, Guatemala and Japan International Cooperation Agency (JICA).

** 吾妻 健：高知医科大学寄生虫学教室（テ781-51 南国市岡豊町小蓮)

*** 上本䁿一：京都府立医科大学医動物学教室 ( $\overline{\mathbf{T}} 602$ 京都市上京区河原町広小路) every morphospecies that has been examined cytogenetically has proven to be divisible into several chromosomally distinct sibling species (Rothfels, 1979). But, these species present considerable problems both in terms of their identification (cytotypes cannot usually be determined in the adult stages) and the initial establishment of their species status.

Usefulness of isozymes for species or strain differentiation has been given recognition especially in the field of medical entomology (Bullini and Coluzzi, 1978; Taylor and 
Muller, 1979). Townson (1976) described an electrophoretic approach to separate members of the Simulium damnosum group. $\mathrm{He}$ found that isozymes of phosphoglucomutase (PGM) in S. yahense were different from those in the other cytotypes. In 1977, May et al. applied electrophoretic methodology to three species of the Simulium jenningsi complex from Maine, USA, which are identifiable in the larval and pupal stages although the adults are morphologically indistinguishable (May et al., 1977), and were able to associate the principal anthropophilic blackfly with its larval and pupal stages by means of four key enzymes.

In this paper, we present an isozyme study of Guatemalan blackflies including a vector species of Guatemalan human onchocerciasis in an attempt to use isozymes as a species diagnosis.

\section{Materials and Methods}

Wild-caught blackflies were used in this experiment. Adult females of $S$. ochraceum were captured in the morning at Finca Rincón, Department of Guatemala. Each flying female attracted to human bate was collected by hand aspirators. Flies collected were brought back to the laboratory and kept at $-80^{\circ} \mathrm{C}$ until electrophoresed. Simulium ochraceum and $S$. horacioi larvae were also obtained from a small stream in the same area of Rincón where $S$. ochraceum adults were sampled. The $S$. metallicum larvae were collected from a stream in Anguiatu, which is close to the border between Guatemala and El Salvador. After species identification of alive samples, they were preserved at $-80^{\circ} \mathrm{C}$. All collections were done from May to July, 1983.

Here, we examined seven enzymes in both adults and larvae: adenylate kinase (AK:EC 2.7.4.3), alkaline phosphatase (ALP:EC 3.1.3.1), glucosephosphate isomerase (GPI: EC 5.3.1.9), $\alpha$-glycerophosphate dehydrogenase $(\alpha$ GPD:EC 1.1.1.8), hexokinase (HK:EG 2.7.1.1), leucine aminopeptidase (LAP:EG 3.4.1.1), phosphoglucomutase (PGM:EC 2.7.5.1).

The collected flies were individually homogenized with a teflon homogenizer in $25 \mu \mathrm{l}$ of distilled water. The resultant homogenates were centrifuged at $3,000 \mathrm{rpm}$ at room temperature for $5 \mathrm{~min}$. The extracts were absorbed onto $5 \times 4 \mathrm{~mm}$ pieces of filter paper, which were then inserted into a horizontal starch gel $(26 \times 16 \times 0.7 \mathrm{~cm})$ prepared as described by Agatsuma and Suzuki (1981). The buffer system and staining mixture for each enzyme are shown in Tables 1 and 2, respectively (Shaw and Prasad, 1970).

\section{RESUlts}

1) Comparison of electrophoretic profiles between larvae and adults of S. ochraceum from Rincón

In order to examine differences in the patterns between larvae and adults, all seven

Table 1 Buffer systems and electrophoretic conditions for each enzyme examined.

\begin{tabular}{|c|c|c|c|}
\hline \multicolumn{4}{|l|}{ Buffer system } \\
\hline Systems & \multicolumn{2}{|r|}{ Electrode buffer } & Gel buffer \\
\hline SI & \multicolumn{2}{|c|}{$0.155 \mathrm{M}$ Tris, $0.043 \mathrm{M}$ citrate } & Dilute $66.7 \mathrm{ml}$ of electrode buffer to $1 l$ \\
\hline $\mathrm{S} 18$ & \multicolumn{2}{|c|}{$\begin{array}{l}0.1 \mathrm{~m} \text { Tris, } 0.1 \mathrm{M} \text { maleic acid, } \\
0.01 \mathrm{M} \mathrm{Na} \mathrm{NaDTA}_{2} \mathrm{H}_{2} \mathrm{O} \\
0.01 \mathrm{M} \mathrm{MgCl}_{2}, 0.13 \mathrm{M} \mathrm{NaOH}\end{array}$} & Dilute $100 \mathrm{ml}$ of electrode buffer to $1 \mathrm{l}$ \\
\hline POULIK & \multicolumn{2}{|c|}{$0.3 \mathrm{~m}$ Boric acid, $0.06 \mathrm{~m} \mathrm{NaOH}$} & $0.076 \mathrm{M}$ Tris, $0.005 \mathrm{M}$ citrate \\
\hline \multicolumn{4}{|c|}{ Electrophoretic conditions } \\
\hline \multicolumn{2}{|c|}{ Systems } & Enzymes & Conditions \\
\hline SI & $\mathrm{AK}$ & $\alpha \mathrm{GPD}$ & $25 \mathrm{~mA}$ current const. $4.0 \mathrm{hr}$ \\
\hline $\mathrm{S} 18$ & GPI & PGM & $70 \mathrm{~mA}$ current const. $15.0 \mathrm{hr}$ \\
\hline POULIK & ALP & LAP & $250 \mathrm{~V}$ voltage const. $5.0 \mathrm{hr}$ \\
\hline
\end{tabular}


Table 2 Staining mixtures for each enzyme.

\begin{tabular}{|c|c|c|c|c|c|}
\hline \multirow{2}{*}{$\frac{\text { Enzymes }}{\mathrm{AK}}$} & \multirow{2}{*}{$\begin{array}{l}\text { Substrates } \\
\text { Glucose }\end{array}$} & \multirow{2}{*}{$\begin{array}{c}\text { Coenzymes } \\
\text { NADP }\end{array}$} & \multicolumn{3}{|c|}{ Other additions } \\
\hline & & & MTT & PMS & $\mathrm{ADP}$ \\
\hline & $40.0 \mathrm{mg}$ & $2.0 \mathrm{mg}$ & $2.0 \mathrm{mg}$ & $2.0 \mathrm{mg}$ & $10.0 \mathrm{mg}$ \\
\hline & & & $\mathrm{MgCl}_{2}$ & G6PD & $\mathrm{HK}$ \\
\hline & & & $80.0 \mathrm{mg}$ & $2 \mathrm{U}$ & $2 \mathrm{U}$ \\
\hline \multirow[t]{4}{*}{ ALP } & $\alpha$-naphtyl acid phosphate & - & \multicolumn{3}{|c|}{ Fast blue RR salt } \\
\hline & sodium salt & & \multicolumn{3}{|c|}{$50.0 \mathrm{mg}$} \\
\hline & $50.0 \mathrm{mg}$ & & \multicolumn{3}{|c|}{$\mathrm{MgCl}_{2}$} \\
\hline & & & $100.0 \mathrm{mg}$ & & \\
\hline \multirow[t]{2}{*}{$\alpha \mathrm{GPD}$} & $\mathrm{Na}-\alpha$-glycerophosphate & NAD & MTT & \multicolumn{2}{|l|}{ PMS } \\
\hline & $20.0 \mathrm{mg}$ & $2.0 \mathrm{mg}$ & $2.0 \mathrm{mg}$ & \multicolumn{2}{|l|}{$2.0 \mathrm{mg}$} \\
\hline \multirow[t]{2}{*}{ GPI } & Fructose-6-phosphate & NADP & MTT & PMS & G6PD \\
\hline & $4.0 \mathrm{mg}$ & $2.0 \mathrm{mg}$ & $2.0 \mathrm{mg}$ & $2.0 \mathrm{mg}$ & $2 U$ \\
\hline \multirow[t]{4}{*}{ HK } & Glucose & NADP & MTT & PMS & $\mathrm{MgCl}_{2}$ \\
\hline & $40.0 \mathrm{mg}$ & $2.0 \mathrm{mg}$ & $2.0 \mathrm{mg}$ & $2.0 \mathrm{mg}$ & $80.0 \mathrm{mg}$ \\
\hline & & & ATP & G6PD & \\
\hline & & & $10.0 \mathrm{mg}$ & $2 \mathrm{U}$ & \\
\hline \multirow[t]{3}{*}{ LAP } & L-leucyl- $\beta$-naphthyl- & - & \multirow{2}{*}{\multicolumn{2}{|c|}{$\begin{array}{l}\text { Black K salt } \\
20.0 \mathrm{mg}\end{array}$}} & \multirow{2}{*}{$\begin{array}{l}\mathrm{MgCl}_{2} \\
20.0 \mathrm{mg}\end{array}$} \\
\hline & amide $\mathrm{HCl}$ & & & & \\
\hline & $20.0 \mathrm{mg}$ & & & & \\
\hline \multirow[t]{4}{*}{ PGM } & Glucose-1-phosphate & NADP & MTT & PMS & $\mathrm{MgCl}_{2}$ \\
\hline & $50.0 \mathrm{mg}$ & $2.0 \mathrm{mg}$ & $2.0 \mathrm{mg}$ & $2.0 \mathrm{mg}$ & $20.0 \mathrm{mg}$ \\
\hline & & & G6PD & G-1,6-P & \\
\hline & & & $2 U$ & trace & \\
\hline
\end{tabular}

Table 3 Differences in enzyme activity on the gel between larvae and adults of $S$. ochraceum.

\begin{tabular}{|c|c|c|c|}
\hline \multirow{2}{*}{ Enzymes } & \multirow{2}{*}{ Loci involved } & \multicolumn{2}{|c|}{ Enzyme activity } \\
\hline & & Larvae & Adults \\
\hline 1. Adenylate kinase & $\mathrm{AK}$ & + & + \\
\hline \multirow[t]{2}{*}{ 2. Alkaline phosphatase } & ALP-1 & + & - \\
\hline & ALP-2 & + & + \\
\hline 3. $\alpha$-Glycerophosphate dehydrogenase & $\alpha \mathrm{GPD}$ & - & + \\
\hline 4. Glucosephosphate isomerase & GPI & + & + \\
\hline 5. Hexokinase & HK & + & + \\
\hline \multirow[t]{2}{*}{ 6. Leucine aminopeptidase } & LAP-1 & + & - \\
\hline & LAP-2 & + & - \\
\hline 7. Phosphoglucomutase & PGM & + & + \\
\hline
\end{tabular}

enzymes were checked using larvae and adults originated from Rincón. Three of seven enzymes examined, ALP, $\alpha$ GPD, and LAP, were found to show differences in their patterns (Fig. 1 and Table 3).

a) Alkaline phosphatase (ALP): In the larval stage, two banding zones appeared, indicating two loci responsible for their activities, while in the adult stage, the cathodal zone did not appear.

b) $\alpha$-glycerophosphate dehydrogenase ( $\alpha$ $G P D)$ : Adult flies showed one strong 


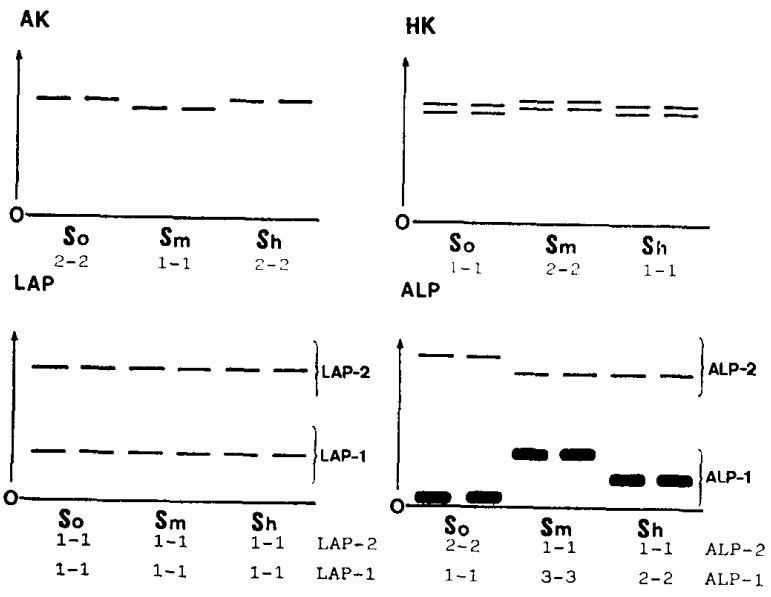

Fig. 1 Electrophoretic patterns of four enzymes, AK, HK, LAP and ALP at the larval stages of the three species of Guatemalan blackflies, Simulium ochraceum, $S$. horacioi and $S$. metallicum.

band of activity, but the larvae had no band.

c) Leucine aminopeptidase (LAP): Like ALP, two banding zones were active in the larvae, indicating the involvement of two loci in enzyme activity, while both zones lost activity in the adult stage.

2) Comparison of electrophoretic patterns among three species, S. ochraceum, S. metallicum and $\mathrm{S}$. horacioi

To compare the isozyme patterns of three species, we examined the activity of six enzymes in the larval stage by electrophoresis.

a) Adenylate kinase ( $A K)$ : We examined 30 individuals for each species. All three species had only one band, and there was no polymorphism. Band mobility of two species, $S$. ochraceum and $S$. horacioi, was the same, but that of $S$. metallicum was a little slower. According to conventional isozyme genetics, these patterns suggest that $S$. ochraceum and $S$. horacioi have the same allele at this locus, differing in this respect from $S$. metallicum (Table 4).

b) Alkaline phosphatase (ALP): There were two zones of activity in all three species. Two loci may be responsible for these two zones; we designated them ALP-1 and ALP2 in order of increasing mobilities. At the ALP-1 locus, different alleles occur in the respective species, while at the ALP-2 locus, the same allele was found in $S$. horacioi and $S$. metallicum. We examined 30 individuals for each species, but, there was no variation in any species examined (Table 4).

c) Glucosephosphate isomerase (GPI): Variation was observed in all three species; there were five different phenotypes as shown in Figs. 2 and 3. From the pattern, we

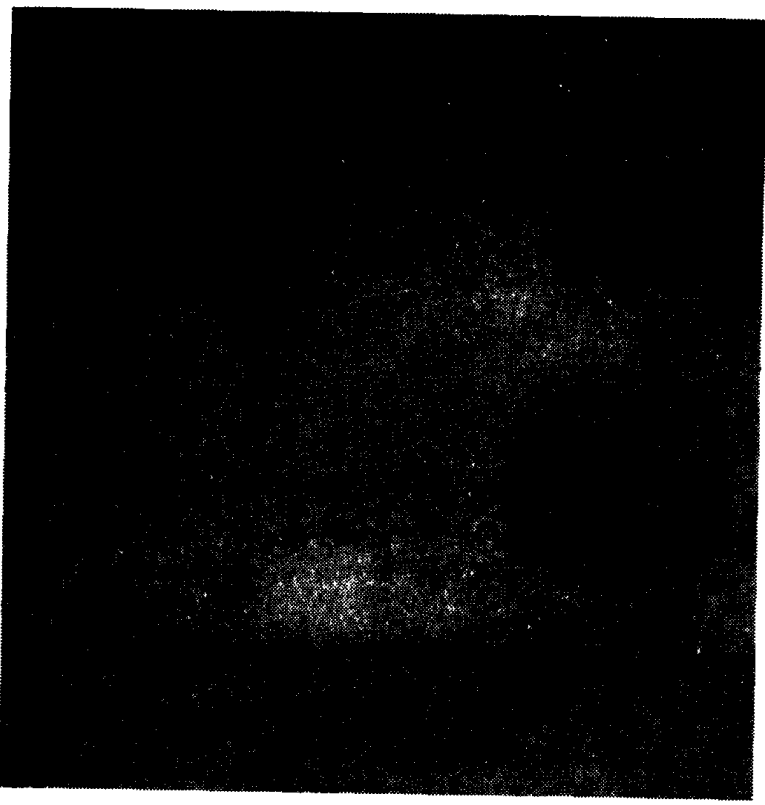

Fig. 2 Electrophoretic profiles of the GPI of $S$. ochraceum and $S$. metallicum.

The first eleven (from left to right) bands are from individual larvae of $S$. ochraceum, and the rest of the bands from individual larvae of $S$. metallicum. a: $1-1 ; \mathrm{b}: 1-2 ; \mathrm{c}$ : $1-3 ; \mathrm{d}: 1-4$.

Table 4 Genotype frequencies at six loci in the three Simulium species from Guatemala.

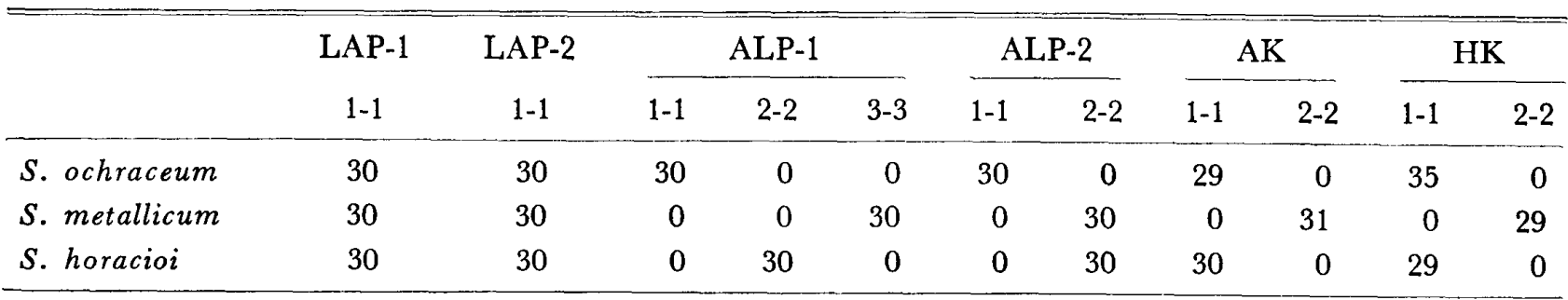


Table 5 The presumptive genotype and allele frequencies at GPI locus in the three different species populations in Guatemala.

\begin{tabular}{|c|c|c|c|c|c|c|c|c|c|c|}
\hline \multirow{2}{*}{ Spe ies } & \multicolumn{6}{|c|}{ Genotypes } & \multicolumn{4}{|c|}{ Allele frequencies } \\
\hline & $1-1$ & $1-2$ & $2-2$ & $1-3$ & $1-4$ & Total & 1 & 2 & 3 & 4 \\
\hline S.o. & 42 & 10 & 2 & 1 & 0 & 55 & 0.864 & 0.127 & 0.009 & 0.000 \\
\hline S.m. & 40 & 6 & 0 & 0 & 2 & 48 & 0.917 & 0.063 & 0.000 & 0.020 \\
\hline$S . h$. & 43 & 1 & 0 & 0 & 3 & 47 & 0.957 & 0.011 & 0.000 & 0.032 \\
\hline
\end{tabular}

\section{GPI}

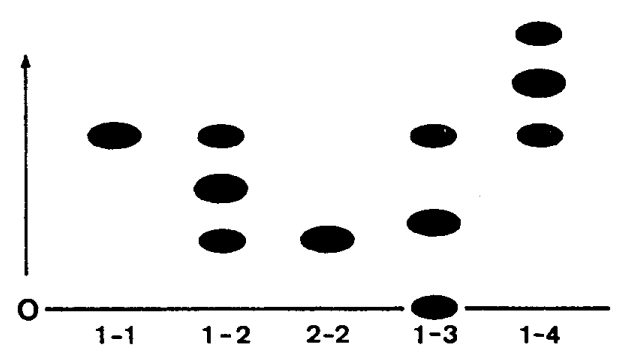

Fig. 3 Diagrammatic representation of electrophoretic patterns of GPI in three species, $S$. ochraceum, S. metallicum and $S$. horacioi.

speculate that a single band will be a homozygote and a triplet band, a heterozygote. Genotype and allele frequencies are shown in Table 5. In total we found four alleles in the Simulium populations examined. Alleles 1 and 2 were common in all three species and allele 1 was the most frequent in all species. Allele 3 was observed in only $S$. ochraceum, while allele 4 was found in $S$. horacioi and S. metallicum.

d) Hexokinase (HK): Thirty individuals from each species were surveyed. A double banding pattern was detected and there was no variation in any species. From the patterns, we concluded that only one locus was involved. The same band mobility was obtained in $S$. ochraceum and $S$. horacioi, while that of $P$. metallicum was faster than the others (Table 4).

e) Leucine aminopeptidase (LAP): There were two remote banding zones, indicating two loci. This was supported by the fact that there is a difference in the adult stage activity between the two zones. Thirty individuals were examined for each species,

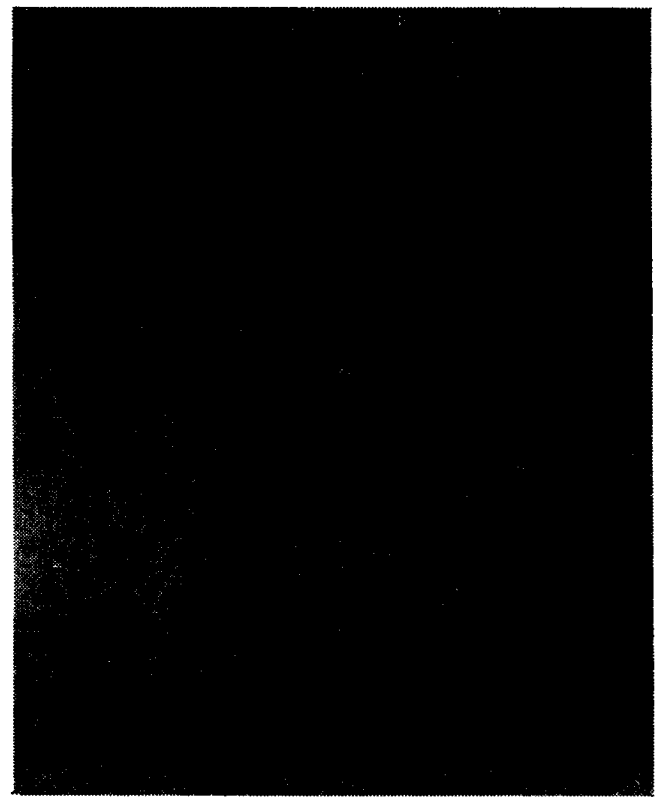

Fig. 4 Electrophoretic profiles of PGM in $S$. ochraceum.

a: $5-5 ; \mathrm{b}: 3-5 ; \mathrm{c}: 1-6 ; \mathrm{d}: 1-5 ; \mathrm{e}: 5-6$.

but neither intra- nor interspecific variation was observed in either zone (Table 4).

f) Phosphoglucomutase (PGM): There was high polymorphism in each species, as in the case of GPI (Figs. 4 and 5). We found a single or two bands in all populations examined. Thus, we speculate that a single band will be a homozygote, and two banded pattern, a heterozygote. In $S$. metallicum, four alleles were observed, while five were found in $S$. horacioi and $S$. ochraceum. As shown in Table 6, allele distribution was very similar in $S$. metallicum and $S$. horacioi, but quite different in $S$. ochraceum. Except for alleles 6 and 7, no allele of $S$. ochraceum was found in common with the other species. Allele 5 was the highest in frequency in $S$. ochraceum, while allele 8 was predominant 
Table 6 The presumptive genotype and allele frequencies at PGM locus in three species of Simulium in Guatemala.

\begin{tabular}{|c|c|c|c|c|c|c|c|c|c|c|c|c|c|}
\hline \multirow{2}{*}{ Species } & \multicolumn{13}{|c|}{ Genotypes } \\
\hline & $1-5$ & $1-6$ & $3-5$ & $4-6$ & $5-5$ & $5-6$ & $5-7$ & $6-6$ & $6-8$ & $7-8$ & $8-8$ & $8-9$ & $8-10$ \\
\hline \multirow{5}{*}{$\begin{array}{l}\text { S.o. } \\
\text { S.m. } \\
\text { S.h. }\end{array}$} & 5 & 1 & 3 & & 16 & 3 & 2 & & & & & & \\
\hline & & & & 2 & & & & 6 & 9 & & 14 & 1 & \\
\hline & & & & & & & & & 3 & 7 & 21 & 3 & 2 \\
\hline & \multicolumn{13}{|c|}{ Allele frequencies } \\
\hline & \multicolumn{2}{|l|}{1} & 3 & \multicolumn{2}{|l|}{4} & 5 & 6 & \multicolumn{2}{|c|}{7} & 8 & \multicolumn{2}{|c|}{9} & 10 \\
\hline S.o. & \multirow{3}{*}{\multicolumn{2}{|c|}{0.100}} & 0.050 & \multirow{3}{*}{\multicolumn{3}{|c|}{0.031}} & 0.067 & \multirow{2}{*}{\multicolumn{2}{|c|}{0.033}} & & \multirow{2}{*}{\multicolumn{2}{|c|}{0.016}} & \\
\hline S.m. & & & & & & & 0.359 & & & 0.594 & & & \\
\hline$S . h$. & & & & & & & 0.042 & \multicolumn{2}{|c|}{0.097} & 0.791 & \multicolumn{2}{|c|}{0.042} & 0.028 \\
\hline
\end{tabular}

PGM

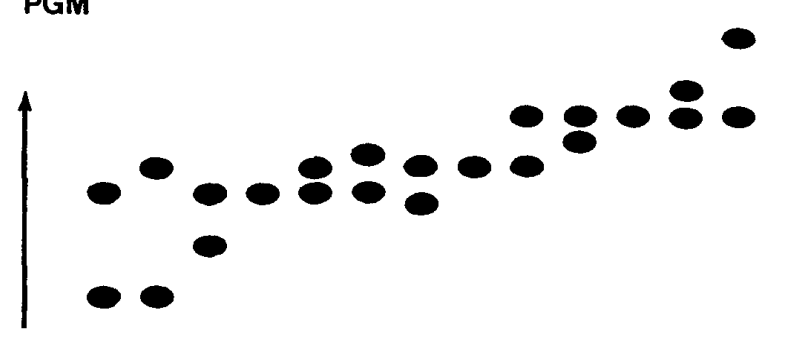

$\begin{array}{lllllllllllll}1-6 & 1-6 & 3-5 & 5-5 & 5-6 & 5-7 & 4-6 & 6-6 & 6-8 & 7-8 & 8-8 & 8-9 & 8-40\end{array}$

Fig. 5 Diagrammatic representation of electrophoretic patterns of PGM in S. ochrace$u m, S$. metallicum, and $S$. horacioi.

in both $S$. metallicum and $S$. horacioi.

\section{Discussion}

Simuliid blackflies are small dipterous insects whose developmental stage occurs in the running water of streams and rivers. The most important parasite transmitted to man by simuliids is Onchocerca volvulus, which produces a severe form of blindness known as river-blindness.

Identification of adult simuliids is often extremely difficult, the females of many species being virtually inseparable on the basis of morphology (Townson and Meredith, 1979). Enzyme electrophoresis has been developed into a powerful tool for clarifying sibling species and species groups (for review, see Lewontin, 1974; Avise, 1975; Markert, 1975). Since the first ap- plication of this method to identification of Simulium damnosum s.l. (Coker, 1973), many studies on blackfly isozymes have been reported (Townson, 1976; May et al., 1977; Townson et al., 1977; Meredith, 1982; Petersen, 1982; Snyder and Linton, 1983, 1984). In the present study, we attempted to characterize three Guatemalan species, Simulium ochraceum, $S$. metallicum and $S$. horacioi, by means of enzyme patterns.

The blackflies examined here are very hard to colonize in the laboratory, and we were not able to carry out crossing experiments to confirm the genetic mode of each enzyme variant. So, we gave tentative genotypes to the respective phenotypes on the basis of the number of electrophoretic bands, their mobilities and the relative intensity of staining, according to conventional procedures adopted for various kinds of species (e.g. Markert, 1975).

When we compared the enzyme patterns between larvae and adults in $S$. ochraceum, three enzymes, ALP, $\alpha$ GPD and LAP, revealed differential activities. The same phenomenon was observed in other two species. This suggests that there is a certain common regulatory system in gene activity during metamorphosis in blackflies.

The main vector of Guatemalan onchocerciasis is $S$. ochraceum. Recently, a new species has been discovered and named " $S$. horacioi" (Okazawa and Onishi, 1980); it is morphologically very similar to $S$. metallicum, which is a possible vector of oncho- 
cerciasis in Guatemala.

In order to evaluate differences in isozyme patterns, we first calculated the ratios of shared major alleles in two out of the three species (Tables 7 and 8 ). The largest value of $A_{\mathrm{D}}$ (allelic distance) was obtained between $S$. ochraceum and $S$. metallicum, showing the closest genetic relationship. Secondly, a quantitative measure of genetic differentiation between species was obtained by calculating Nei's index (Nei, 1972) of genetic distance, $D$, for each pairwise comparison of populations, using the data on

Table 7 The distribution of alleles shared among the three species of Simulium.

\begin{tabular}{lcccc}
\hline Enzyme & Allele* & $\begin{array}{c}S . \\
\text { ochraceum }\end{array}$ & $\begin{array}{c}S . \\
\text { metallicum }\end{array}$ & $\begin{array}{c}S . \\
\text { horacioi }\end{array}$ \\
\hline AK & 1 & obs** $^{*}$ & $\mathrm{n}$ & obs \\
& 2 & $\mathrm{n}^{* *}$ & obs & $\mathrm{n}$ \\
ALP-1 & 1 & obs & $\mathrm{n}$ & $\mathrm{n}$ \\
& 2 & $\mathrm{n}$ & $\mathrm{n}$ & obs \\
& 3 & $\mathrm{n}$ & obs & $\mathrm{n}$ \\
ALP-2 & 1 & obs & $\mathrm{n}$ & $\mathrm{n}$ \\
& 2 & $\mathrm{n}$ & obs & obs \\
GPI & 1 & obs & obs & obs \\
HK & 1 & obs & $\mathrm{n}$ & obs \\
& 2 & $\mathrm{n}$ & obs & $\mathrm{n}$ \\
LAP-1 & 1 & obs & obs & obs \\
LAP-2 & 1 & obs & obs & obs \\
PGM & 5 & $\mathrm{n}$ & obs & obs \\
& 8 & $\mathrm{n}$ & obs & obs \\
\hline
\end{tabular}

* It shows the alleles with the highest frequency in either species.

** Obs indicates that the alleles listed are observed in a given species, and $\mathrm{n}$ indicates that they are not. allelic frequencies. The formula is given by the following equation;

$$
D=-\ln \left(\overline{\sum q_{i j^{\bullet}} q_{i k}} / \sqrt{\overline{\sum q_{i j}{ }^{2} \cdot \overline{\sum q_{i k}{ }^{2}}}}\right),
$$

where $q_{i j}$ and $q_{i k}$ are the allele frequencies of the $i$-th allele at a locus in the taxa, or populations, $j$ and $k$, respectively, and the average is taken over all the loci examined. The estimates of genetic distance $(D)$ between populations are summarized in Table 9. The lowest estimate of $D$ was 0.4211 between $S$. ochraceum and $S$. horacioi. This value was not so far from the estimate between $S$. metallicum and $S$. horacioi. The value between $S$. ochraceum and $S$. metallicum was relatively higher. The result is consistent with $A_{\mathrm{D}}$ value from allelic difference estimate. Morphologically and phylogenetically, $S$. horacioi is very close to $S$. metallicum as mentioned above, and the genetic distance between them was well within the usual range for inter-specific populations (Nevo, 1978). However, the value, on the whole, did not differ much from that between $S$. horacioi and $S$. metallicum, or S. metallicum and S. ochraceum, which are phylogenetically distant from each other. Although the meaning of the discrepancy is unknown at present, this fact indicated that isozyme study will provide important information for the current morphological taxonomy of blackflies. Further analysis of this phenomenon is in progress.

\section{AGKNOWLEDGeMents}

We express hearty thanks to all the staff members in SNEM of Guatemala for their kind

Table 8 The allelic differences between the three species of Simulium.

\begin{tabular}{lrrr}
\hline & S.o. $-S . m$. & S.o. $-S . h$. & S.m. $-S . h$. \\
\hline The allele number shared between two species & 3 & 5 & 5 \\
Total number of alleles compared* & 14 & 14 & 14 \\
Allelic similarity $\left(A_{\mathbf{S}}\right)^{* *}$ & 0.214 & 0.357 & 0.357 \\
Allelic distance $\left(A_{\mathrm{D}}\right)^{* * *}$ & 1.542 & 1.030 & 1.030 \\
\hline
\end{tabular}

* See Table 7.

** $A \mathrm{~s}=$ (The number of major alleles shared at eight loci between two species)/(Total number of alleles compared).

*** $A_{\mathrm{D}}=-\ln A_{\mathrm{S}}\left(0<A_{\mathrm{S}}<1\right)$. 
Table 9 Genetic similarity $\left(I^{*}\right)$ and genetic distance $\left(D^{*}\right)$ calculated on the basis of the gene frequencies at eight loci coding for AK, ALP, GPI, HK, LAP and PGM in the larval stages of the three Simulium species.

\begin{tabular}{|c|c|c|c|c|}
\hline & & \multicolumn{3}{|c|}{$D$} \\
\hline & & S.o. & $S . m$. & S.h. \\
\hline \multirow{3}{*}{$I$} & S.o. & & 0.9545 & 0.4324 \\
\hline & $\{. m$. & 0.3850 & & 0.5336 \\
\hline & S.h. & 0.6490 & 0.5865 & \\
\hline
\end{tabular}

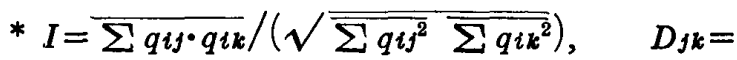
$-\log _{e} I$. The $q i j$ and $q i k$ are the frequencies of the $i$-th allele at a locus in the $j$-th and $k$-th populations respectively, and the average was over all the gene loci examined including loci without variation.

cooperation and encouragement. We are also indebted to Prof. Noriji Suzuki, Assoc. Prof. Yoshihisa Hashiguchi, and Conrad Zagory Jr., Lecturer, Kochi Medical School, for their helpful criticism and review of this manuscript.

\section{REFERENCES}

Agatsuma, T. and N. Suzuki (1981): Electrophoretic studies on enzymes in Paragonimus. I. Comparison of isozyme patterns between $P$. ohirai and P. miyazakii. Jpn. J. Parasitol., 30: 7-13.

Avise, J. C. (1975): Systematic value of electrophoretic data. Syst. Zool., 23: 465-481.

Bullini, L. and M. Coluzzi (1978): Applied and theoretical significance of electrophoretic studies in mosquitoes (Diptera: Culicidae). Parassitologia, 20: 7-21.

Coker, W. Z. (1973): Electrophoretic patterns in Anopheles gambiae and Simulium damnosum. Ann. Trop. Med. Parasitol., 67: 475-481.

Lewontin, R. C. (1974): The Genetic Basis of Evolutionary Change, 346 pp., Columbia University Press, New York and London.

Markert, G. L. (1975): Isozyme IV. Genetics and Evolution, 965 pp., Academic Press, New York.

May, B., L. S. Bauer, R. L. Vadas and J. Granett (1977): Biochemical genetic variation in the family Simuliidae: Electrophoretic identification of the human biter in the isomorphic Simulium jenningsi group. Ann. Entomol. Soc. Am., 70: 637-640.

Meredith, S. E. O. (1982): Enzyme identification of Simulium damnosum s.l. caught biting man.
Ann. Trop. Med. Parasitol., 76: 375-376.

Nei, M. (1972): Genetic distance between populations. Am. Nat., 106: 283-292.

Nevo, E. (1978): Genetic variation in natural populations: Patterns and theory. Theor. Popul. Biol., 13: 121-177.

Okazawa, T. and O. Onishi (1980): Description of a new species of Simulium (Simulium) Latreille and redescription of Simulium (Simulium) metallicum Bellardi from Guatemala (Diptera: Simuliidae). Jpn. J. Sanit. Zool., 31: 167-179.

Petersen, J. L. (1982): Population genetics of some new world Simuliidae. In: Recent Developments in the Genetics of Insect Disease Vectors (eds., Steiner, W. W. M., W. J. Tabachnick, K. S. Rai and S. Narang), pp. 628642, Stipes Pupl. Co., Champaign.

Rothfels, K. H. (1979): Cytotaxonomy of blackflies (Simuliidae). Annu. Rev. Entomol., 24: 507-539.

Shaw, C. R. and R. Prasad (1970): Starch gel electrophoresis of enzymes-A compilation of recipes. Biochem. Genet., 4: 297-320.

Snyder, T. P. and M. C. Linton (1983) : Electrophoretic and morphological separation of Prosimulium fuscum and $P$. mixtum larvae (Diptera: Simuliidae). Can. Entmol., 115: 81-87.

Snyder, T. P. and M. G. Linton (1984): Population structure in black flies: Allozymic and morphological estimates for Prosimulium mixtum and P. fuscum (Diptera: Simuliidae). Evolution, 38: 942-956.

Taylor, A. E. R. and R. Muller (1979): Problems in the Identification of Parasites and Their Vectors, 110 pp., Blackwell Scientific Publications, Oxford.

Townson, H. (1976): Enzyme polymorphisms in vectors of disease-its study and interpretation of results: Studies of enzymes in the Simulium damnosum complex and Aedes scutellaris group. WHO Publ., VBC/SC/76: 21.

Townson, H. and S. E. Meredith (1979): Identification of the Simuliidae in relaiton to onchocerciasis. In: Problems in the Identification of Parasites and Their Vectors (eds., Taylor, A. E. R. and R. Muller), pp. 145-174, Blackwell Scientific Publications, Oxford.

Townson, H., S. E. Meredith and K. Thomas (1977): Enzyme differences between species of the Simulium damnosum complex. Trans. $R$. Soc. Trop. Med. Hyg., 71: 111. 


\section{摘要}

ブユアイソザイムの遺伝生化学的研究 I. グァテマラ産ブュ 3 種 Simulium ochraceum, S. metallicum, S. horacioi 間のアイソザイム変異

グァテマラ産ブユ 3 種, Simulium ochraceum, $S$. metallicum, S. horacioi の酵素の電気泳動パターン を基にそれらの類稼関係を比較検討した. 調査した 7 酵素, adenylate kinase (AK), alkaline phosphatase (ALP), $\alpha$-glycerophosphate dehydrogenase $(\alpha \mathrm{GPD})$, glucosephosphate isomerase (GPI), hexokinase (HK), leucine aminopeptidase (LAP), phosphoglucomutase (PGM) のうち3酵素, ALP, $\alpha$ GPD， LAP は，幼虫から成虫の発生段階において 醳素活性パターンに変動がみられ，ALP と LAP は 成虫， $\alpha \mathrm{GPD}$ は幼虫においてそれぞれ活性バンドを 失った.これは,ブュの変態過程において酵素活性に 何らかの調節機構があることを示すものと思われる. 種間の比較は, 幼虫期の $\alpha \mathrm{GPD}$ を除いた 6 醭素で行 った.
GPI，PGM の2䣼素は，すべての種内で変異が見 いだされ，高度に多型的であったが，これらの変異は 一部種間で共有していた. 一方, AK, ALP, HK, LAP の 4 酵素は，種内変異はみられなかったが，種 間には大きな違いがみられた。種間の遺伝的距離は。

Nei （1972）の方法および比較した種間で共有してい る優勢な対立遺伝子の割合 $\left(A_{\mathrm{D}}\right)$ を求める方法の 2 方 法を用いて推定したところ，両法ともほぼ同様の結果 に達した. すなわち, S. ochraceum-S. metallicum 間の Nei の遺伀的距離 $(D)$ は, 形態学的見地加推 測されるよらに大きい值 $(0.9545)$ を示したが， $S$. metallicum-S. horacioi 間 (0.5336) では, S. ochraceum-S. horacioi 間 $(0.4324)$ とほぼ同程度の值が 得られ, S. metallicum-S. horacioi 間の形態的類似 性とややくい違いを見せた。. また S. ochraceum-S. horacioi 間で得られた $D$ 值は，0.4324 であり,こ の值はこれらの形態的相違から考えると予想に反し小 さかった，共有する対立遺伝子の割合， $A_{\mathrm{D}}$ ，も $\mathrm{Nei}$ のD值とほぼ同様に $S$. ochraceum-S. metallicum 間で最大の值が得られ，S. ochraceum-S. horacioi 間 とS. metallicum-S. horacioi 間では同じ值が得られ た. 